\title{
Bone Marrow Suppression
}

National Cancer Institute

\section{Source}

National Cancer Institute. Bone Marrow Suppression. NCI Thesaurus. Code C744440.

A condition in which the production of red blood cells, white blood cells, and/or platelets

by bone marrow stem cells is inhibited, usually as a side effect of treatment with various anti-cancer agents, radiation, or tumor development within the bone marrow. 